\title{
Catcalling sebagai Bentuk Pelecehan Seksual Traumatis
}

\section{Catcalling as a Traumatic Form of Sexual Harassment}

\author{
Saffana Zahro Qila1 ${ }^{1}$ Rizki Nur Rahmadina², Fadhlin Azizah3 \\ 1,2,3 Program Studi Ilmu Komunikasi, Universitas Islam Indonesia, Sleman \\ Yogyakarta, Indonesia
}

\section{Author's email: \\ ${ }^{1}$ saffanaqila@gmail.com \\ ${ }^{2}$ rizkinurrahmadina135@gmail. com \\ 3fadhlinazizah13@gmail.com}

\begin{abstract}
Catcalling events are now quite familiar, especially in big cities like Yogyakarta, where the population is full of students and college students. Catcalling involves a different experience for everyone. The purpose of this study was to know in depth the experiences and reactions of a person when experiencing catcalling. This research is qualitative research using the phenomenological method. The results of this study indicate that catcalling is a form of verbal sexual harassment and has a negative impact on the victim's life. The informant who became a victim of catcalling chose to remain silent even though it had a deep impact, even to a traumatic experience. Therefore, victims need to voice their interests to get wide attention.
\end{abstract}

Keywords: catcalling, experience, reaction, sexual harassment, verbal communication,

Peristiwa catcalling sekarang menjadi hal yang cukup familiar, terutama di kota besar seperti Yogyakarta yang penduduknya dipadati oleh pelajar dan mahasiswa. Catcalling melibatkan pengalaman yang berbeda-beda bagi setiap orang. Tujuan penelitian ini adalah mengetahui secara mendalam pengalaman dan reaksi seseorang ketika mengalami catcalling. Penelitian ini merupakan suatu penelitian kualitatif dengan menggunakan metode fenomenologi. Hasil penelitian ini menunjukkan bahwa catcalling merupakan salah satu bentuk pelecehan seksual verbal dan menimbulkan dampak negatif bagi kehidupan korban. Informan yang menjadi korban catcalling ini memilih diam meskipun memberikan dampak mendalam, bahkan hingga ke pengalaman traumatis. Oleh karena itu, penting bagi korban untuk menyuarakan kepentingan mereka agar mendapatkan perhatian luas

Kata kunci: catcalling, komunikasi verbal, pengalaman, pelecehan seksual reaksi 


\section{PENDAHULUAN}

Pelecehan seksual tidak lagi menjadi kata asing di kalangan masyarakat, dan semua orang memiliki kemungkinan untuk menjadi korban. Dilansir dari Catatan Tahunan Komnas Perempuan 2020, terdapat 29.911 kasus kekerasan seksual di Indonesia sepanjang 2020 (Komnas Perempuan, 2021). Survei Pelecehan Seksual di Ruang Publik pada 2019, terdapat sebanyak 64\% dari 38.755 perempuan, dan $11 \%$ dari 28.403 laki-laki. Dari data tersebut, sebanyak 60 persen mengaku pelecehan yang didapat berupa secara verbal atau ucapan, $24 \%$ mengalami sentuhan dan $15 \%$ melalui visual seperti tatapan mata atau main mata (Farisa, 2019).

Pelecehan seksual secara verbal menjadi bentuk pelecehan yang paling sering dialami oleh masyarakat. Pelecehan seksual secara verbal ini seringkali terjadi di ranah publik yang berarti kasus terjadi dimana korban dan pelaku tidak memiliki hubungan kerabat ataupun tidak saling mengenal satu sama lain.

Hidayat dan Setyanto (2020) menjelaskan catcalling merupakan hal yang nyata dan dapat disaksikan menggunakan panca indera. Catcalling biasanya dilakukan oleh segerombol orang, dan pelakunya seringkali adalah laki-laki dan korbannya perempuan walaupun tidak menutup kemungkinan jika korbannya laki-laki dan pelakunya adalah perempuan.

Terdapat interaksi berbentuk simbol-simbol dalam kegiatan catcalling yang memiliki implikasi terhadap pola komunikasi antara pelaku dan korban catcalling. Simbol-simbol yang dilakukan pelaku catcalling bertujuan untuk menggoda atau mengganggu seseorang di jalanan. Dalam interaksi yang terjadi tersebut, muncul simbol-simbol maupun isyarat yang merendahkan korban.
Catcalling diindikasikan adanya kesalahan dalam interaksi antara laki-laki dan perempuan. Dalam masyarakat masih terdapat perspektif soal martabat laki-laki lebih tinggi dibandingkan perempuan. Perempuan dianggap lemah, sedangkan laki-laki dianggap lebih kuat dan lebih dominan. Dalam hal ini, terdapat ketimpangan relasi kuasa antara laki-laki dan perempuan.

Catcalling bisa dialami siapapun tanpa memandang memandang umur. Penelitian ini dilakukan dengan mengambil subjek Mahasiswi Universitas Islam Yogyakarta. Mahasiswi yang sedang dan sudah melewati masa remaja, memiliki banyak pengalaman terkait banyak hal. Salah satunya pengalaman Catcalling.

Pengalaman catcalling tentu saja bukan menjadi pengalaman baik bagi yang pernah mengalaminya. Catcalling dapat dimasukkan ke dalam pelecehan seksual, dan dampak yang ditimbulkan pengalaman catcalling pun beragam. Dampak paling parah adalah trauma terhadap hal yang bersangkutan, dan mengingatkan kejadian tersebut terusmenerus.

Penelitian terkait dengan catcalling sudah beberapa kali dilakukan. Hidayat dan Setyanto (2020) dalam penelitiannya mengatakan bahwa catcalling mengandung bentuk komunikasi, yaitu saat pelaku memberikan ekspresi verbal terhadap korbannya melalui siulan atau komentar mengenai bagian atribut seksual tubuh korban. Penelitian mereka menunjukkan bahwa catcalling merupakan pelecehan seksual secara verbal dan merupakan bentuk dari rape culture atau budaya pemerkosaan. Sebuah konsep sosiologi untuk keadaan dimana pemerkosa dianggap wajar dan normal karena sikap masyarakat terhadap gender dan seksualitas. 
Rahman (2019) dalam penelitiannya memaparkan pelecehan seksual secara verbal kerap terjadi di ruang publik, dan korbannya adalah perempuan dan tidak sedikit diantaranya merupakan perempuan yang berjilbab. Fokus penelitian ini adalah bagaimana mahasiswi berjilbab di Kota Surabaya memaknai pelecehan seksual verbal berdasarkan pengalaman yang didapatkan. Penelitian tersebut menjelaskan bahwa mahasiswi berjilbab memaknai pelecehan seksual verbal berbeda-beda, sesuai dengan penafsiran mereka. Perbedaan disebabkan penafsiran, penilaian, dan penyempurnaan makna yang dilakukan, dan hal ini dipengaruhi oleh simbol-simbol pelecehan verbal yang dilakukan pelaku pada korbannya.

Kurniawan (2016) Kurniawan dalam penelitiannya membahas tentang pelecehan seksual yang terus meningkat karena perkembangan teknologi dan globalisasi sekaligus membahas bagaimana komunikasi interpersonal membentuk persepsi tentang diri, baik secara sosial, fisik, maupun psikologis. Dari penelitian ini, ditemukan bahwa proses komunikasi interpersonal menjadi hal yang sangat penting dalam proses pembentukan konsep diri negatif menjadi positif.

Farmer dan Smock Jordan (2017) melakukan penelitian mengenai kesadaran dan kepedulian akan pelecehan seksual dalam berbagai bentuk dan terus mengalami peningkatan. Penelitian tersebut menyarankan pentingnya mengetahui upaya untuk mengatasi catcalling dengan respon yang berbedabeda dari tiap narasumber. Upaya penanganan dikembalikan kepada diri masing-masing, tetapi harus disertai keputusan dan pengetahuan yang dapat dipertanggungjawabkan.

O’Leary (2016) melakukan penelitian mengenai pentingnya wanita yang menjadi korban pelecehan seksual catcalling untuk menyuarakan hal yang pernah dialami dan kerugian serta efek yang dirasakan. Fenomena catcalling bersifat kompleks, dan wanita mengkonseptualisasikannya sebagai pengalaman negatif utama karena mereka mengaitkan dengan emosi negatif dan keadaan afektif. Selain itu, perempuan yang menjadi korban merasa bahwa pengalaman dan persepsi mereka tentang catcalling sangat sering diacuhkan oleh laki-laki dan masyarakat karena catcalls seringkali dibingkai sebagai pujian.

Penelitian ini dilakukan untuk mengetahui secara mendalam mengenai pengalaman, bentuk-bentuk catcalling, reaksi mahasiswi dan dampak yang dialami mahasiswi terkait pengalaman Catcalling. Harapannya, dengan dilakukannya penelitian ini, akan dapat membuat masyarakat lebih peduli terkait catcalling.

\section{KERANGKA TEORI}

Hidayat dan Setyanto (2020)
mendefinisikan catcalling sebagai penggunaan kata-kata yang tidak senonoh, ekspresi secara verbal dan nonverbal yang kejadiannya terjadi di tempat umum atau publik. Catcalling secara verbal biasanya dilakukan dengan siulan atau komentar mengenai penampilan korban, sedangkan secara nonverbal dapat berupa penggunaan gestur fisik. Ada pembuktian bahwa tempat umum seringkali menjadi tempat dimana pelecehan oleh orang asing terjadi karena pelecehan yang dilakukan orang asing ini di tempat umum, maka tempat-tempat seperti taman beserta angkutan umum dirasa kurang aman bagi wanita yang sering mengalami catcalls (Eastwood, 2015).

Definisi lain mengenai catcalling, yaitu melakukan hal-hal yang bertendensi seksual kepada orang yang lewat di jalanan atau berada di tempat umum dan membuat orang yang bersangkutan merasa tidak nyaman dan atau terancam. Korban 
catcalling biasanya akan melakukan self objectification, yaitu secara sadar atau tanpa sadar melakukan penilaian dengan melibatkan lima unsur; who, says what, in which channel, to whom, and effect (Suciati, 2017). Pelaku catcalling umumnya melakukan hal tersebut sebagai candaan untuk menarik perhatian dari korban. Maraknya catcalling belakangan ini didukung oleh kemajuan teknologi yang kemudian menghasilkan reaksi berbedabeda, bergantung pada kondisi, pendidikan, latar belakang, usia, serta gender.

Puspitasari (2019: 2) menyatakan bahwa catcalling sering dialami oleh beberapa perempuan yang ada di berbagi tempat di belahan dunia ini. Dengan kata lain, sebagian besar perempuan di dunia sudah pernah mengalami catcalling. Menurut survei yang dilakukan oleh American Seal, ada $71 \%$ wanita di dunia pernah mengalami catcalling dan 53\% diantaranya mendapat pelecehan secara fisik. Bentuk catcalling disampaikan melalui tiga jenis pesan verbal, yakni verbal vokal yaitu pesan disampaikan secara vokal, verbal visual yaitu ketika penyampaian pesan secara verbal menggunakan visualisasi yang dapat ditangkap penglihatan, kemudian verbal vocal-visual, yaitu pengucapan kata-kata menggunakan vokal dan dibantu dengan adanya visualisasi (Liliweri, 2009).

Catcalling merupakan bentuk pelecehan seksual karena melibatkan pelaku, korban, dan hal yang berbau seksual. Dalam masyarakat, peristiwa ini dianggap hal biasa dan sebagai wujud budaya patriarki karena kejadiannya di tempat umum dan melibatkan banyak saksi sehingga ada pewajaran di dalamnya (Stellarosa et al., 2018). Anggapan ini membuat catcalling terus terjadi secara berulang-ulang. Catcalling dianggap pelecehan seksual kategori ringan, banyak korban yang tidak menyadari bahwa sebenarnya ia telah menjadi objek/korban catcalling. Beberapa dampak yang dialami setelah korban mengalami catcalling, diantaranya berkurangnya rasa aman dan nyaman, merasa pergerakannya di ruang publik terbatas, merasa malu dan tidak percaya diri, ataupun bisa mengganggu mental.

Hal yang melatarbelakangi terjadinya catcalling sangat kompleks karena tidak ada faktor inti, hanya perlu melihat sejauh mana nilai serta norma yang ada dalam masyarakat diterapkan. Arivia (2018) menegaskan bahwa secara garis besar ada 2 faktor, yang menjadi latar belakang terjadinya catcalling, yakni faktor biologis dan faktor sosial budaya. Faktor biologis (natural) ditunjukan ketika laki-laki memiliki dorongan seksual lebih besar daripada perempuan sehingga sebagian besar pelaku adalah laki-laki. Faktor sosial budaya menunjukkan bahwa catcalling adalah wujud dari sistem patriarki, dan anggapan ini sudah membudaya dan tertanam dalam pikiran masyarakat. Selain karena catcalling dianggap budaya patriarki, penyebab utama ketertindasan perempuan adalah seksualitas dan sistem gender.

Saparwati et al. (2013) menyatakan bahwa pengalaman dapat diartikan sebagai memori episodik atau ingatan yang menyimpan peristiwa yang sedang terjadi atau dijalani oleh individu pada waktu atau tempat tertentu dan berfungsi sebagai referensi otobiografi selama waktu hidup seseorang. Pengalaman terjadi secara pribadi pada saat seseorang merespon stimuli, misalnya, saat sedang mengalami catcalling bisa sebelum maupun setelah kejadian. Kejadian catcalling memiliki aspek pengalaman dan berasal dari suatu set interaksi antara korban dan pelaku atau bagian dari seseorang yang memprovokasi reaksi dengan menunjukkan keterlibatan korban pada tingkatan berbeda-beda.

Macmillan et al. (2000) menyatakan bahwa salah satu efek pengalaman catcalling berupa membatasi 
kebebasan dan pergerakan milik seseorang. Pengalaman catcalling memiliki definisi yang terkait dengan peristiwa, yaitu ketika pengalaman korban catcalling merupakan respon subjektif dan internal dari dalam diri seorang korban yang berinteraksi/kontak secara langsung dengan pelaku. Tiap individu memiliki pengalaman yang beragam dalam hidupnya walaupun melihat objek yang sama karena dipengaruhi oleh jenjang atau tingkat pendidikan yang dimiliki seseorang, umur, latar belakang, pekerjaan, objek yang dipersepsikan, dan juga faktor situasi ketika suatu peristiwa terjadi (Notoatmodjo et al., 2012)

Saparwati et al. (2013) menyatakan bahwa pengalaman memiliki sifat yang subjektif sehingga antara individu satu dengan yang lainnya akan memiliki pengalaman yang berbeda-beda, dan dipengaruhi oleh isi memori yang dirasakan oleh tiap orang. Sifat pengalaman yang subjektif berkaitan dengan dampak yang dirasakan oleh korban catcalling. Ada korban yang hanya merasa takut tetapi ada juga yang sampai trauma. Pengalaman yang dialami oleh seseorang terdiri dari tiga dimensi, diantaranya pengalaman sensorik, pengalaman sosial, dan juga pengalaman emosional.

Pengalaman sensorik memberikan pengaruh pada panca indera atau sebagai first impression saat peristiwa melalui stimulus sensorik. Pengalaman sosial berkaitan dengan naluri alamiah manusia, yaitu sifat sosialis, setiap pengalaman sosial memberikan dampak pada seseorang dan akan mengubah perilaku yang dimiliki seseorang dalam bersosialisasi (Schmitt, 2003). Pengalaman emosional berkaitan dengan suasana hati seseorang, emosi yang dirasakan seseorang saat mengalami peristiwa akan menentukan hasil yang positif atau hasil negatif.
Pengalaman yang dimaksud dalam penelitian ini lebih menitikberatkan pada pengalaman korban catcalling yang dibangun dengan melibatkan emosional, kognitif, afektif, sosial, dan respon fisik terhadap suatu peristiwa. Pengalaman tiap orang akan berbeda saat merasakan peristiwa dan dapat dirasakan secara sensorik, sosial, maupun emosional sehingga pengalaman yang dirasakan korban catcalling sangat penting untuk diketahui dan dapat membangun pengalaman yang baik (Mapp dalam Saparwati et al., 2013)

\section{METODE}

Penelitian menggunakan metode kualitatif dalam rangka menggali dan mengungkapkan kesamaan makna dari sebuah konsep atau fenomena yang menjadi pengalaman hidup sekelompok individu dengan strategi fenomenologi. Tujuan penelitian fenomenologi adalah mereduksikan pengalaman individual terhadap suatu fenomena ke dalam deskripsi yang menjelaskan tentang esensi universal dari suatu fenomena serta untuk memahami fenomena yang dialami oleh subjek penelitian.

Penelitian ini menggunakan metode fenomenologi dengan alasan bahwa fokus penelitian ini adalah memahami pengalaman catcalling sebagai pelecehan verbal yang dialami oleh mahasiswa. Fokus penelitian ini adalah melihat bagaimana pengalaman mahasiswi di Universitas Islam Indonesia mengenai fenomena catcalling.

Mahasiswa Universitas Islam Indonesia dipilih menjadi subjek observasi agar peneliti tidak kesulitan dalam menjaring informasi yang diteliti, melihat aspek umur, pola pikir, dan latar belakang. Data dikumpulkan melalui wawancara mendalam.

Wawancara mendalam dipilih sebagai teknik pengumpulan data dalam penelitian ini karena dirasa cukup 
membantu peneliti untuk mendapatkan data yang diinginkan. Wawancara dilakukan kepada korban catcalling untuk mengetahui pendapat dan reaksi mereka saat mengalami tindakan seksual secara verbal, dan agar mengetahui bagaimana hukum dan dampak negatif dari catcalling, serta untuk membantu peneliti dalam melihat dan mengetahui keberagaman pengalaman individu mengenai fenomena catcalling. Ada enam mahasiswa yang menjadi informan penelitian ini.

Teknik analisis data yang digunakan oleh penelitian adalah analisis kualitatif mengikuti konsep (Miles et al., 2014). Analisis data dilakukan secara interaktif melalui proses reduksi data, penyajian data, dan penarikan kesimpulan. Adapun analisis data yang dilakukan peneliti, yaitu dengan merangkum terlebih dahulu hasil studi kepustakaan dan observasi yang terkait dengan pengalaman catcalling .

\section{HASIL DAN PEMBAHASAN}

Penelitian ini menemukan beberapa kategori yang berkaitan dengan hasil wawancara seperti pengalaman, reaksi korban ketika terjadi catcalling, bentuk-bentuk catcalling, dan dampak yang dialami korban.

\section{Pengalaman Catcalling}

Pengalaman dapat diartikan sebagai sesuatu yang pernah dialami, dijalani maupun dirasakan, baik sudah lama maupun yang baru saja terjadi (Mapp dalam Saparwati et al., 2013) Pengalaman adalah pengamatan yang merupakan kombinasi penglihatan, penciuman, pendengaran serta pengalaman masa lalu (Saparwati et al., 2013). Dari beberapa pendapat tersebut, dapat disimpulkan bahwa pengalaman adalah sesuatu yang pernah dialami, dijalani maupun dirasakan yang kemudian disimpan dalam memori.

Pengalaman catcalling yang dialami para informan memiliki ceritanya masing-masing. Informan 1 mengatakan bahwa pengalaman catcalling yang dialaminya tidak hanya secara verbal, tetapi juga fisik.

"Kejadiannya di Jakal [jalan Kaliurang] dan pada malam hari. Aku membonceng temanku yang juga perempuan dan dipepet oleh laki-laki yang berkendara dengan gerombolannya. Aku mendapatkan perkataan yang kurang sopan dan juga bagian tubuhku ada yang disentuh (pantat). Aku dan temanku tidak berani membalas apa-apa karena terlalu takut soalnya jalanan sudah sepi dan aku berdua cewe semua”. (informan 1, wawancara, 2021).

Pengalaman informan 2 terjadi pada saat sedang pergi bersama temantemannya ketika dijalan tiba-tiba ada segerombolan laki-laki yang mengendarai motor dan mereka kurang lebih mengucapkan "cewek cewek" dengan tujuan memanggil dan menggoda (informan 2, wawancara, 2021).

Informan 3 mengaku adanya pengalaman catcalling yang paling berbekas adalah saat masih di bangku SMP. Pada saat itu, ia sedang berjalan kaki pulang ke rumah. Saat sedang berada di gang yang posisinya sudah dekat dengan rumah, Ia melihat ada segerombolan lakilaki di gang tersebut. Karena terlalu jauh jika memutar balik, Ia memutuskan untuk melewati gang tersebut. Ketika ia lewat, segerombolan laki-laki itu memanggil dengan ucapan menggoda seperti "Assalamualaikum, mba", "jalan mba?" (informan 3, wawancara, 2021). 
Catcalling yang dialami pada informan 4 terjadi pada malam hari ketika akan pulang ke rumah.

"Waktu itu aku abis pergi, mau pulang kerumah sekitar jam setengah 10 malam. Itukan jalanan sudah mulai sepi, ya terus pas di lampu merah ada mas-mas berdua kek ngesuit-suitin sama manggilmanggil mba-mba gitu. Terus habis dari lampu merah, dia ngikutin aku kek cukup jauh gitu akhirnya aku mampir ke warung temenku dulu”. (informan 4, wawancara, 2021).

Kejadian yang terjadi pada informan 5 terjadi pada saat jalan kaki ke pasar bersama dengan kakaknya. Saat melewati sebuah warung yang ramai dan banyak laki-laki, para laki-laki tersebut melontarkan panggilan menggoda dan bersiul-siul (informan 5, wawancara, 2021). Informan 6 pun mengalami hal yang sama. Ketika sedang berjalan dan melewati segerombolan laki-laki, mereka melontarkan panggilan menggoda yang di rasa kurang nyaman oleh informan (informan 6, wawancara, 2021).

Setelah mengetahui berbagai cerita dari pengalaman-pengalaman para korban catcalling, pengalaman yang dialami oleh para informan berbeda-beda, dan kejadian tersebut bahkan berdampak menjadi trauma bagi si korban. Jadi, dapat diketahui bahwa catcalling dapat terjadi dimana dan kapan saja kepada kita, jadi kita harus lebih berhati-hati lagi.

\section{Bentuk-bentuk Catcalling}

Dalam Kamus Besar Bahasa Indonesia, bentuk memiliki banyak definisi dan fungsi yang berbeda-beda tergantung pada penempatan serta penggunaannya. Dalam penelitian ini, bentuk yang dimaksud adalah wujud maupun gambaran yang ditampilkan. Bentuk yang ditampilkan kemudian membuat manusia melakukan penilaian terhadap aksi yang ditampilkan.

Penelitian ini menemukan bahwa sebagian besar informan mengalami peristiwa catcalling dalam bentuk verbal. Seperti yang disampaikan oleh informan 3 yang menerangkan bahwa ketika sedang berjalan kaki menuju ke rumah, dan sudah dekat rumah segerombol laki-laki menggodanya.

"Mungkin karena pakai jilbab jadi kayak "Assalamualaikum, mba" "jalan mba?" gitu. Waktu SMA, karena naik motor kalo berhenti di lampu merah dan sebelahnya mobil (biasanya yg naik mobil) yang suka gini "mba mba" begitu "cantik" apalah itu, mau kabur atau ngejauh juga gimana, harus apa. Paling yang lain kaya' lagi di jalan karena aku pake kacamata "mba yang pake kacamata dicariin nih" "cantik" pokoknya gitu-gitu lah." (informan 3, wawancara 2021).

Selain informan 3 yang mendapatkan godaan secara lisan, informan 2 juga mengaku mengalami catcalling berupa godaan verbal saat di jalan, tetapi bukan sebagai pengendara motor. Informan 2 (Wawancara, 2021) menyatakan bahwa ia mengalami catcalling ketika sedang pergi bersama teman-teman perempuannya, kemudian segerombolan laki-laki yang juga mengendarai motor dan mereka kurang lebih memanggil "cewek-cewek" yang bertujuan untuk menggoda.

Hal yang sama juga dirasakan oleh informan 5. Saat itu, Ia sedang dalam perjalanan dan melewati kedai yang ramai dan banyak laki-laki "disitulah kami mengalami nya di siul-siul bilang cantiklah atau di panggil adek lah pokoknya kayak di goda-goda gitulah." (Informan 5, wawancara, 2021). Panggilan dan siulan yang ditujukan oleh pelaku 
untuk menggoda korban merupakan visual dari bentuk pelecehan verbal.

Informan 6 juga mengalami catcalling berbentuk verbal, yaitu penyampaian dengan lisan yang membuat keadaan menjadi kurang nyaman saat sedang jalan melewati sekumpulan anak muda (Informan 6, wawancara, 2021).

Peristiwa catcalling yang dialami oleh informan sebagian besar berupa lontaran kata-kata yang bertujuan menggoda. Namun, berbeda dengan informan 3,2,5, dan 6, informan 1 dan 4 justru mendapatkan catcalling dalam bentuk verbal sekaligus non verbal. Informan 4 menyatakan,

"Dulu abis aku beli makan malam, pas lagi di jalan, ada mobil yang lagi belok otomatis kan harus berhenti ya. Terus tiba-tiba ada orang nyebrang gitu membawa kek tongkat nepok bokongku." (Informan 4, wawancara, 2021)

Hal serupa juga dialami oleh informan 1 yang mendapatkan kata-kaa yang kurang sopan dan sentuhan. Tentunya, hal ini sudah lebih parah daripada bentuk-bentuk sebelumnya yang hanya berbentuk verbal dengan lisan maupun siulan.

Setelah melakukan wawancara pada informan dan hasil menunjukkan bahwa bentuk dari peristiwa catcalling yang dialami oleh informan sebagian besar secara verbal, yaitu lontaran kata yang tidak senonoh atau menggoda dan ada juga yang mendapatkan sentuhan fisik. Hal ini diperkuat dengan penelitian yang dilakukan oleh Hidayat \& Setyanto (2020). Penelitian keduanya menyimpulkan bahwa dalam catcalling mengandung bentuk komunikasi, yaitu secara verbal (vokal, visual, dan vocalvisual). Hasil dan kesimpulan penelitian menunjukkan catcalling merupakan pelecehan seksual secara verbal dan wujud dari rape culture atau budaya pemerkosaan, yaitu sebuah keadaan dimana pemerkosa dianggap wajar dan normal karena sikap masyarakat terhadap gender dan seksualitas.

\section{Respon korban}

Respon tidak hanya sesuatu yang positif, tetapi setiap jenis kegiatan yang ditimbulkan oleh suatu rangsangan dapat pula disebut respon. Secara garis besar, respon dapat diartikan sebagai kesan atau hasil dari suatu pengamatan terhadap peristiwa, subjek atau hubunganhubungan yang diperoleh dengan menyimpulkan informasi dan menafsirkan pesan. Respon dapat berupa reaksi penolakan atau persetujuan dari diri seseorang terhadap pesan yang didapat.

Seluruh pernyataan yang didapat dari informan mengatakan bahwa respon mereka ketika terjadi catcalling hanya dapat diam. Informan 2 mengatakan ketika sedang naik motor bersama temannya kemudian mendapat catcalling dia hanya dapat diam dan langsung menjaga jarak.

Sama dengan yang dilakukan informan 2, informan 4 memilih untuk hanya diam "Aku diem aja, pura-pura ga denger si”. (Informan 4, wawancara, 2021). Kondisi saat itu informan 4 memang sedang mengendarai motor sendirian, sehingga menurutnya hal yang paling aman dilakukan saat itu adalah diam.

Informan 5 pun melakukan hal yang sama, "Saya hanya diam dan mempercepat langkah saya untuk menghindari hal tersebut." (informan 5, wawancara, 2021). Meski sedang berdua dengan kakaknya, dia memilih untuk diam.

Berbeda dengan informan 1, responnya langsung menangis " $A k u$ langsung menangis saat itu juga dan aku takut banget, temenku yang di depan 
juga panik lihat aku nangis karena emang buat kita kejadian ini parah banget," (infoman 1, wawancara, 2021). Saat itu, catcalling yang dialami informan 1 sudah sampai fisik, ada bagian tubuhnya yang disentuh oleh salah satu dari segerombol laki-laki yang mendekatinya.

Jika dari informan 3, responnya

pura-pura tidak peduli, tetapi perasaannya bingung dan takut, informan 6 merasa malu karena itu terjadi ditempat umum Kejadian itu menjadi trauma tersendiri bagi si korban.

Setelah mengetahui pengalamanpengalaman yang terjadi kepada para korban catcalling, sebagian besar respon para korban hanya bisa diam dan menahan rasa takut mereka. Namun, pada akhirnya, menjadi sebuah trauma bagi para korban catcalling.

\section{Dampak yang Dialami Korban}

Dalam Kamus Besar Bahasa Indonesia, dampak memiliki pengertian sebagai benturan, pengaruh yang dapat mendatangkan positif ataupun negatif. Pengaruh sendiri berarti suatu daya yang ada dan timbul dari seseorang ataupun sesuatu yang ikut membentuk kepercayaan, watak atau perbuatan seseorang (Khairunnisa, 2019). Pengaruh ini ada karena suatu keadaan dimana terdapat hubungan timbal balik atau memiliki hubungan sebab akibat antara apa yang mempengaruhi dan dipengaruhi. Penjelasan lain, dampak diartikan sebagai segala sesuatu yang timbul akibat adanya suatu peristiwa yang terjadi di masyarakat dan menghasilkan perubahan yang berpengaruh positif maupun negatif pada kelangsungan hidup.

Penelitian ini menemukan bahwa catcalling memberikan dampak negatif. Sebagian besar menjawab bahwa mereka merasakan ketakutan dan trauma. Informan 1 menyatakan, "aku langsung gak berani bepergian terutama jika menggunakan motor pada malam hari kurang lebih selama 1 minggu. Jika mengingat kejadian itu, aku langsung trauma dan nyalinya langsung ciut, takut banget terulang lagi kejadian kaya gitu." (informan 1, wawancara, 2021)

Hal ini sama dengan yang dirasakan informan 2 bahwa ia mengalami perasaan takut dan trauma. Ia mengatakan bahwa setelah mengalami kejadian catcalling tersebut ia akan lebih memilih tempat ramai ketika pergi sendiri dan akan menghindari gerombolan laki-laki. Informan 4 mengaku bahwa pengalaman catcallingnya ini sempat mengganggu pikirannya dan merasakan trauma.

Perlakukan catcalling yang dilakukan pelaku sangatlah tidak nyaman dan membuat risih. Berbeda dari informan 1 dan 2, informan 5 mengatakan bahwa dia tidak merasakan trauma, tetapi merasa risih atas perlakukan pelaku. "Trauma sih gakya tapi ya jadi gak nyaman gitu atau jadi risih gitulah", demikian Ia mengatakan (informan 5, wawancara, 2021).

Perasaan risih ini dirasakan pula oleh informan 3. Menurutnya, perasaan risih ini tidak hanya dirasakan ketika ketika catcalling dilakukan oleh orang asing. Ia mengatakan bahwa orang yang dikenal pun bisa melakukan catcalling dan hal tersebut sangat tidak nyaman.

"Iya, sebenarnya aku ngerasa ga mesti orang asing, kaya' sebenarnya aku mungkin tau dia siapa, tapi cara mereka aku ga suka dan risih. Seringnya lebih takut, kalo misal dia tau aku siapa kayak lebih mungkin untuk misal tahu-tahu ngedeket [mendekat]." (informan 3, wawancara, 2021). 
Berdasarkan wawancara yang telah dilakukan dengan semua informan, dampak catcalling yang mereka alami adalah perasaan negatif. Dampak negatif yang mereka rasakan ini mereka rasakan untuk waktu yang cukup lama.

Dari apa yang sudah dipaparkan di atas, dapat disimpulkan bahwa pengalaman catcalling ini dapat dialami oleh siapa saja, kapan saja dan dimana saja. Catcalling yang paling sering terjadi berbentuk verbal berupa ucapan lisan yang menggoda dan mengganggu. Namun, tidak menutup kemungkinan bahwa catcalling dapat terjadi dalam bentuk fisik, menyentuh anggota tubuh korban. Pelakunya seringkali laki-laki yang sedang bergerombol.

Respon yang diberikan korban, kebanyakan hanya bisa diam. Mereka mengaku merasa takut dan merasa bahwa itu merupakan hal yang paling aman untuk dilakukan. Pengalaman catcalling ini membawa dampak negatif terhadap korban yang pernah mengalaminya seperti perasaan trauma ketika dipertemukan di kondisi serupa.

Catcalling yang kerap dilakukan oleh segerombolan laki-laki kepada perempuan. Membuat sang korban tidak berani melawan, dan memilih diam meski sedang tidak sendiri. Hal ini meneguhkan hasil penelitian O'Leary (2016) yang berjudul "Catcalling as a "Double Edged Sword": Midwestern Women, Their Experiences, and the Implications of Men's Catcalling Behaviors". Dalam penelitiannya, ditemukan hasil bahwa fenomena catcalling itu kompleks. Wanita mengkonseptualisasikannya sebagai pengalaman negatif utama karena mereka mengaitkan dengan emosi negatif dan keadaan afektif. Selain itu, perempuan yang menjadi korban merasa bahwa pengalaman dan persepsi mereka tentang catcalling sangat sering diacuhkan oleh laki-laki dan masyarakat karena catcalls seringkali dibingkai sebagai pujian.
Penelitian ini juga meneguhkan penelitian Farmer dan Smock Jordan (2017) berjudul "Experiences of Women Coping With Catcalling Experiences in New York City: A Pilot Study". Respon korban terhadap catcalling seringkali lebih memilih untuk diam sehingga Farmer dan Smock Jordan (2017) menemukan pentingnya mengetahui upaya untuk mengatasi catcalling dengan respon yang berbeda-beda dari tiap narasumber. Upaya penanganan dikembalikan kepada diri masing-masing tetapi harus disertai keputusan dan pengetahuan yang dapat dipertanggung jawabkan.

\section{KESIMPULAN}

Penelitian ini menunjukkan bahwa semua informan yang catcalling tanpa mereka ketahui siapa pelakunya, dan tidak tau alasannya mereka mendapat catcalling dari orang yang tidak diketahui. Waktu terjadinya pun tidak tentu, tidak hanya di saat malam hari, atau hanya siang hari. Pelakunya seringkali segerombol laki-laki yang berpapasan dengan informan.

Hasil penelitian ini menunjukkan bahwa catcalling yang dialami oleh informan kebanyakan dalam bentuk verbal. Seringkali, pelaku melontarkan kata-kata yang bertujuan menggoda seperti "mbak, mbak", "cantik", "assalamualaikum mbak", dan sebagainya. Namun, terdapat informan yang mendapat catcalling secara fisik, berupa sentuhan di anggota tubuh tertentu.

Dari seluruh informan yang kami diwawancara, informan hanya diam dengan alasan ketika kejadian tersebut mereka memang sedang sendiri, dan merasa lebih aman jika hanya diam. Namun, informan lainnya pun mengaku meski sedang bersama seseorang dan tidak sendirian, mereka tetap tidak berani untuk melakukan tindakan lain.

Seluruh informan mengaku bahwa mereka mengalami dampak negatif dari pengalaman catcalling tersebut. Perasaan 
takut yang muncul ketika kejadian tersebut menimbulkan trauma dikemudian hari. Mereka menjadi merasa segan dan takut ketika melewati segerombolan laki-laki, kemudian memilih untuk menghindar.

Dari hasil penelitian yang ditemukan, peneliti menyarankan untuk lebih berhati-hati ketika bepergian, usahakan untuk menghindari wilayah yang sepi ketika bepergian sendiri. Ini karena catcalling ini bisa dialami siapa saja dan kapan saja. Peneliti juga menyarankan kepada para korban yang mengalami catcalling untuk berani speak up dan bertindak. Ini penting dalam membangun kesadaran lebih luas mengenai bahaya catcallin.

\section{DAFTAR PUSTAKA}

Arivia, G. (2018). Filsafat berperspektif feminist. In JYP Press (Edisi Kedu).

Eastwood, E. (2015). What, can't you take a compliment?: A qualitative study of catcalling.

Farisa, F. C. (2019). Survei KRPA: Perempuan 13 kali lebih rentan alami pelecehan seksual di ruang publik. Kompas.Com. https://nasional.kompas.com/read/2 019/11/27/13414591/survei-krpaperempuan-13-kali-lebih-rentanalami-pelecehan-seksual-diruang? page $=$ all

Farmer, O., \& Smock Jordan, S. (2017). Experiences of women coping with catcalling experiences in New York city: A pilot study. Journal of Feminist Family Therapy, 29(4), 205-225. https://doi.org/10.1080/08952833.2 017.1373577

Hidayat, A., \& Setyanto, Y. (2020). Fenomena catcalling sebagai bentuk pelecehan seksual secara verbal terhadap perempuan di Jakarta. Koneksi, 3(2), 485. https://doi.org/10.24912/kn.v3i2.64 87
Khairunnisa. (2019). Dampak pola komunikasi Awkarin melalui vlog Karin Novilda terhadap perilaku mahasiswa Fakultas Dakwah dan Komunikasi UIN Raden Fatah [UIN Raden Fatah]. In UIN Raden Fatah Palembang. http://eprints.radenfatah.ac.id/4139 /

Komnas Perempuan. (2021). CATAHU 2020 komnas perempuan: Lembar fakta dan poin kunci. Komnasperempuan.Go.Id. https://komnasperempuan.go.id/siar an-pers-detail/catahu-2020-komnasperempuan-lembar-fakta-dan-poinkunci-5-maret-2021

Kurniawan, S. O. (2016). Proses komunikasi interpersonal perempuan korban pelecehan seksual dengan pendamping dalam pembentukan konsep diri di Yayasan Embun Surabaya. Jurnal E-Komunikasi, 4(2).

https://publication.petra.ac.id/index. php/ilmukomunikasi/article/view/4834

Liliweri, A. (2009). Makna budaya dalam komunikasi antarbudaya. In LKiS Yogyakarta. 
Macmillan, K., Money, K., \& Downing, S. (2000). Successful business relationships. Journal of General Management, 26(1), 69-83. https://doi.org/10.1177/0306307000 02600105

Miles, M. B., Huberman, A. M., \& Saldana, J. (2014). Qualitative data analysis: A methods sourcesbook. In $S A G E$ (Edisi 3).

Notoatmodjo, S., Anwar, H., Nurlaeli, E., \& Tri, K. (2012). Promosi kesehatan di sekolah. In rineka cipta.

O'Leary, C. (2016). Catcalling as a "Double edged sword": Midwestern women, their experiences, and the implications of men's catcalling behaviors [Illinois State University]. https://doi.org/10.30707/ETD2016. OLeary.C

Puspitasari, Y. N. H. (2019). Catcalling dalam perspektif gender, Maqasid syariah dan hukum pidana (Studi Pada Mahasiswi Fakultas Syariah dan Ilmu Hukum IAIN Tulungagung). In UIN Satu Tulungagung.
Rahman, N. Al. (2019). Pelecehan seksual verbal pada mahasiswi berjilbab (Studi tentang pemaknaan pengalaman pelecehan seksual verbal bagi mahasiswi berjilbab di Kota Surabaya) [Universitas Airlangga]. In Universitas Airlangga.

http://repository.unair.ac.id/id/epri nt/84345

Saparwati, M., Sahar, J., \& Mustikasari. (2013). Studi fenomenologi: Pengalaman kepala ruang dalam mengelola ruang rawat di RSUD Ambarawa. Prosiding Konferensi Nasional Ppni Jawa Tengah.

Schmitt, D. (2003). Insights into the evolution of human bipedalism from experimental studies of humans and other primates. Journal of Experimental Biology, 206(9), 14371448.

https://doi.org/10.1242/jeb.00279

Stellarosa, Y., Firyal, S. J., \& Ikhsano, A. (2018). Pemanfaatan youtube sebagai sarana transformasi majalah highend. LUGAS Jurnal Komunikasi, 2(2), 59-68. https://doi.org/10.31334/ljk.v2i2.26 3

Suciati. (2017). Teori komunikasi dalam multi perspektif. In Buku Litera Yogyakarta. 